\title{
Gambaran Kematangan Emosi Siswa TK B yang Memiliki Kematangan Kognitif Tinggi di Sidoarjo
}

\author{
Ayu Rachmawati Rulidha ${ }^{1}$, Lely Ika Mariyati ${ }^{2}$ \\ Fakultas Psikologi dan Ilmu Pendidikan, Universitas Muhammadiyah Sidoarjo \\ email: ${ }^{1}$ ayu.r.rulidha@gmail.com, ${ }^{2}$ ikalely@yahoo.co.id
}

\begin{abstract}
The purpose of this study is to describe the description of emotional maturity and factors that influence the emotional maturity of kindergarten B students who have high cognitive maturity in private kindergartens in Sidoarjo. This research is a qualitative research with a phenomenological approach. The research subjects were 3 kindergarten $B$ students who had high cognitive maturity. Determination of research subjects using purposive sampling techniques. Data collection methods using interviews, observation, and documentation. The results showed that each subject showed a picture of emotional maturity and factors that influence in achieving emotional maturity that varies, there are the same and some are different. However, this study cannot reveal the picture on gender, age factors of development and physical changes, because the age of the child is relatively the same and the circumference of the coconut, body weight and height according to the standard age level are also relatively simila. Implications for this study for students who do not have high emotional maturity are expected to teachers and parents to develop emotional maturity of children by considering the characteristics of the child including the child's cognitive.
\end{abstract}

KEYWORDS Cognitive maturity, emotional maturity, kindergarten B children

CITATION Rulidha, A. R., Mariyati, L. I. (2019). Gambaran kematangan emosi siswa TK B yang memiliki kematangan kognitif tinggi di sidoarjo. Cognicia, 7, (4). 446-464.

Masa anak usia dini atau masa anak-anak awal merupakan fase usia emas (golden age), di mana anak akan mengalami perkembangan secara cepat, seperti perkembangan motorik-sensorik, kognitif, emosi, social, dan bahasa. Anak usia dini atau sering disebut dengan anak taman kanak-kanak (TK) adalah anak yang berusia 3 sampai 6 tahun. Biasanya mereka mengikuti program kindergarten atau TK ${ }^{[24]}$. Program kindergarten merupakan jenjang pendidikan dalam bentuk formal yang terbagi menjadi dua, yaitu TK A dan TK B. Masing-masing memiliki kurikulum yang berbeda. TK A diperuntukkan untuk anak usia 3-4 tahun, dengan kurikulum pembelajaran yang lebih mudah, seperti baca tulis hitung (1-10), bermain, dan bernyanyi. TK B untuk anak usia 5-6 tahun memiliki kurikulum pembelajaran yang lebih sulit karena untuk kesiapan memasuki jenjang pendidikan selanjutnya, yaitu Sekolah Dasar (SD).

Anak TK yang mempunyai kesiapan sekolah mendapatkan keuntungan dan kemajuan ketika menghadapi rintangan di $\mathrm{SD}^{[23]}$, sehingga dapat dikatakan bahwa 
kesiapan anak TK B yang akan memasuki SD sangat penting, termasuk matang secara kognitif. Kematangan merupakan suatu proses tercapainya tahapan natural dari transisi fisik dan perilaku, termasuk juga kesiapan untuk menguasai keterampilan baru $^{[11]}$. Kognitif merupakan pemrosesan informasi, yang dimulai dari menerima informasi, masuk ke dalam pikiran, serta penyimpanan dan pengolahan informasi untuk kemudian diambil kembali saat melaksanakan aktivitas yang kompleks, seperti memecahkan masalah dan berfikir ${ }^{[14]}$. Maka, kematangan kognitif adalah anak-anak yang telah mampu mencapai tahapan perkembangan kognitif, termasuk kesiapan untuk menguasai kemampuan baru dalam memproses informasi yang semakin bertambah.

Ciri-ciri kematangan kognitif pada anak prasekolah adalah mampu mengenal bermacam-macam simbol seperti huruf, angka, gambar, dan kata-kata yang digunakan untuk menyebut benda, mampu berpikir kritis, menggunakan penalaran sederhana dalam memecahkan masalah, mampu berkonsentrasi, dan memiliki daya ingat yang baik $^{[23]}$. Oleh karena itu, dalam mencapai kemampuan tersebut, anak TK B diharapkan memiliki kematangan kognitif, sebab berkaitan dengan kemampuan anak dalam menerima dan memproses informasi yang diperolehnya ${ }^{[8]}$. Kematangan kognitif pada anak TK B merupakan aspek penting untuk menunjang kesiapan dalam memasuki sekolah dasar.

Kematangan kognitif yang dimiliki anak TK B dapat dilihat melalui hasil belajar. Perubahan perilaku yang terjadi melalui proses pembelajaran berupa kemampuan siswa setelah menerima pengalaman belajar, yang menjadi hasil perolehan belajar disebut hasil belajar ${ }^{[20]}$. Hasil perolehan belajar tersebut dibukukan menjadi sebuah laporan belajar yang bernama rapor. Sebuah TK swasta di Sidoarjo melakukan penilaian pada siswa berupa rapor menggunakan teknik penilaian dengan kolom pencapaian perkembangan, yaitu 1 (belum berkembang/BB), 2 (mulai berkembang/MB), 3 (berkembang sesuai harapan/BSH), dan 4 (berkembang sangat baik/BSB). Berdasarkan hasil observasi awal, dengan melihat nilai rapor keseluruhan pada siswa TK B di TK swasta di Sidoarjo, diperoleh hasil bahwa terdapat 3 siswa yang memiliki nilai tertinggi pada aspek perkembangan kognitif. Subjek I memiliki nilai 120, subjek II dengan nilai 116, dan subjek III dengan nilai 114 dari 144 total nilai secara keseluruhan.

Perkembangan kognitif sangat berkaitan dengan pertumbuhan fisik dan emosional ${ }^{[12]}$. Kematangan kognitif juga memengaruhi kematangan emosi. Kemampuan dalam memecahkan masalah dan meregulasi diri pada situasi yang berkaitan dengan emosi melibatkan proses kognitif. Penelitian Howse, Calkins, Anastopoulos, Keane, \& Shelton (2003) mengemukakan bahwa pengaturan emosi dan prestasi dimediasi oleh regulasi diri. Regulasi emosi memengaruhi kemampuan anak untuk mengatur pembelajaran mereka sendiri. Selain itu, regulasi emosi dan regulasi diri saling terkait. Beberapa anak yang mengalami kesulitan regulasi emosi di rumah juga mengalami kesulitan dalam tugas-tugas yang diberikan oleh sekolah ${ }^{[5]}$. Kematangan emosi adalah kemampuan untuk tidak meluapkan emosi di hadapan orang-orang, akan tetapi menunggu waktu dan tempat yang tepat untuk mengekspresikan emosinya dengan cara yang bisa diterima oleh lingkungan ${ }^{[6]}$. 
Aspek kematangan emosi pada periode anak prasekolah di antaranya adalah memiliki pemahaman emosi yang dialami, mengetahui emosi orang lain, mengungkapkan kata yang berkaitan dengan emosi yang sesuai pada situasi sosial dan budaya tertentu, memiliki kepekaan empatik dan simpatik pada pengalaman emosional orang lain, memahami kondisi emosional dengan tidak selalu menampakkan dengan ekspresi, coping adaptif terhadap emosi negatif menggunakan strategi self-regulatory yang dapat meminimalisir durasi dan intensitas dari emosi, memiliki kesadaran bahwa ekspresi emosi mewakili peranan dalam hubungan interpersonal, memandang kondisi emosi pada diri sebagai cara untuk mengatur emosinya, mengekspresikan emosi (mendeskripsikan emosi diri sendiri), memahami emosi dalam situasi tertentu, dan dapat meregulasi emosi ${ }^{[15][16]}$.

Kematangan emosi pada anak prasekolah tentunya berbeda-beda. Hal ini disebabkan karena adanya faktor yang memengaruhi kematangan emosi. Terdapat dua faktor penting yang memengaruhi kematangan emosi, yaitu kematangan kognitif (mental) dan proses belajar, yaitu proses belajar mencoba-coba, proses belajar secara imitasi dan proses belajar secara pengondisian ${ }^{[18]}$. Selain itu, terdapat faktor lain yaitu pola asuh orang tua, temperamen, jenis kelamin, usia perkembangan sejalan dengan bertambahnya usia, perubahan fisik, dan interaksi dengan teman sebaya ${ }^{[2]}$. Penelitian Stan (2013) menyatakan bahwa faktor regulasi emosi mewakili prediktor yang menjelaskan variasi kinerja sekolah. Regulasi emosional yang dimiliki siswa akan menunjukkan kompetensi kognitif yang lebih baik, tercermin dalam kinerja sekolah. Thompson (1990) menggambarkan bahwa faktor regulasi emosi terlibat dalam kapasitas organisasi perilaku dan motivasi, proses penghambatan, dan perencanaan ${ }^{[19]}$. Motivasi dapat memengaruhi prestasi akademik seorang siswa. Penelitian Sharma (2018) menyatakan bahwa konsep diri dan motivasi sangat penting untuk prestasi akademik siswa ${ }^{[17]}$.

Emosi anak pada masa anak-anak awal seringkali berubah-ubah dan cenderung diekspresikan secara terbuka dan spontan. Anak akan menunjukkan bentuk-bentuk perilaku ketika merasa senang, marah, takut, cemburu, rasa ingin tahu, sedih, dan peduli secara langsung. Diperkuat dengan hasil penelitian mengenai emosi anak usia dini yang telah dilakukan di Taman Kanak-Kanak di Yogyakarta dengan judul "Prediktor Permasalahan Perilaku Anak Usia Taman Kanak-Kanak", diperoleh hasil bahwa terdapat permasalahan umum yang sering ditemui, seperti agresivitas, kecemasan, temper tantrum, sulit konsentrasi, kesulitan berkomunikasi, menarik diri, enuresis dan encoresis, berbohong, menangis dan takut berlebihan, tergantung, dan pemalu $^{[7]}$. Dalam wawancara yang dilakukan peneliti dengan salah satu guru di TK swasta di Sidoarjo, didapatkan hasil bahwa emosi yang terlihat dari perilaku anakanak TK B masih berubah-ubah. Itu tidak hanya terjadi pada anak yang memiliki kognitif tinggi, tetapi juga pada mereka yang memiliki kognitif sedang ataupun rendah. Seiring dengan hasil wawancara, peneliti melihat ada kesamaan fenomena yang terjadi di TK swasta di Sidoarjo, yaitu masih dijumpai siswa-siswi TK B yang memiliki kematangan kognitif dalam kategori rata-rata atau tinggi, namun belum memiliki kematangan emosi yang cukup.

Penelitian ini terinspirasi dari hasil observasi terhadap 3 siswa TK B yang memiliki kematangan kognitif tinggi, yaitu SA, TT, dan RN. Hasil menunjukkan 
bahwa 2 siswa yaitu SA dan T menunjukkan kematangan emosi. SA menunjukkan aspek pemahaman emosi, yakni ketika guru bernyanyi dan bertepuk. TT menunjukkan aspek kepekaan empatik dan simpatik terhadap pengalaman emosi orang lain, terihat saat ia melihat temannya tidak membawa bekal, TT menawarkan dan memberi sebagian bekal yang dibawa. TT pun melakukan coping adaptif terhadap emosi negatif menggunakan strategi self-regulatory ketika temannya mengganggu dirinya dengan mengambil alat masakan dan melemparkannya ke wajah. TT terdiam, takut dan berlari mengadu pada guru serta berusaha untuk tidak membalas dengan kekerasan. Sedangkan 1 siswa lain, yaitu RN kurang menujukkan kematangan emosi terutama pada aspek menyadari ekspresi emos yangi mewakili peranan dalam hubungan interpersonal. Ketika balok RN direbut oleh temannya, RN tetap mempertahankan baloknya dan terjadi saling tarik menarik sambil berteriak.

Dari paparan di atas, maka tujuan dilakukannya penelitian ini adalah untuk mengetahui gambaran kematangan emosi siswa TK B yang memiliki kematangan kognitif tinggi dan mengetahui faktor-faktor yang memengaruhi kematangan emosi siswa TK B yang memiliki kematangan kognitif tinggi di TK swasta di Sidoarjo

Adapun manfaat dari penelitian ini secara teoritis adalah diharapkan penelitian ini dapat berguna untuk menambah referensi ataupun ilmu pengetahuan mengenai bentuk-bentuk kematangan emosi siswa yang memiliki kematangan kognitif tinggi. Manfaat secara praktis yaitu semoga dapat memberikan informasi mengenai gambaran emosi anak usia prasekolah pada orang tua dan guru sebagai individu dewasa yang memiliki peran penting dalam mendampingi perkembangan siswa, sehingga mereka mampu memberikan respon dengan tepat kepada siswa, khususnya pada anak yang memiliki kematangan emosi rendah.

\section{Siswa TK B yang Memiliki Kematangan Kognitif}

Menurut Ketentuan Umum UU No. 20 Tahun 2003 mengenai Sistem Pendidikan Nasional, peserta didik atau siswa adalah publik yang sedang berupaya dalam memperluas potensi diri melewati proses pembelajaran yang tersedia pada jalur, jenjang, dan jenis pendidikan tertentu ${ }^{[4]}$. Siswa Taman kanak-kanak (TK) adalah individu yang sedang menempuh pendidikan pada jenjang prasekolah atau pendidikan sebelum menempuh pendidikan sekolah dasar. Anak prasekolah adalaj anak yang berusia antara 3 sampai 6 tahun $^{[13]}$. Taman kanak-kanak atau program kindergarten merupakan jenjang pendidikan dalam bentuk formal untuk anak usia 3-6 tahun yang terbagi menjadi dua, yaitu TK A dan TK B dengan kurikulum berbeda. TK B mempersiapkan anak untuk memasuki jenjang sekolah dasar sehingga dibutuhkan kematangan kognitif dan emosi yang lebih tinggi dibandingkan siswa TK A.

Kematangan merupakan suatu proses tercapainya tahapan natural dari transisi fisik dan perilaku, termasuk juga kesiapan untuk menguasai keterampilan baru ${ }^{[11]}$. Kognitif merupakan pemrosesan informasi, yang dimulai dari menerima informasi, masuk ke dalam pikiran, serta penyimpanan dan pengolahan informasi untuk kemudian diambil kembali saat melaksanakan aktivitas yang kompleks, seperti memecahkan masalah dan berfikir ${ }^{[14]}$. Ciri-ciri kematangan kognitif pada anak prasekolah adalah mampu mengenal bermacam-macam simbol seperti huruf, angka, gambar, dan kata-kata yang digunakan untuk menyebut benda, mampu berpikir kritis, 
menggunakan penalaran sederhana dalam memecahkan masalah, mampu berkonsentrasi, dan memiliki daya ingat yang baik ${ }^{[23]}$.

\section{Kematangan emosi}

Menurut Santrock, perilaku mewakili emosi yang muncul dengan menunjukkan ekspresi kenyamanan atau ketidaknyamanan dari situasi atau interaksi yang sedang dihadapi $^{[15]}$. Anak dapat dikatakan matang secara emosi apabila mampu mengendalikan emosinya, sebab dengan terkendalinya emosi maka anak dapat berfikir dengan baik dalam setiap permasalahan yang ia hadapi. Kematangan emosi ialah kemampuan setiap manusia untuk mengutarakan dan mengekspresikan emosinya dengan baik untuk sesuatu hal yang berguna tanpa menghiraukan perasaan yang ada di dalam dirinya ${ }^{[1]}$. Kematangan emosi adalah kemampuan untuk tidak meluapkan emosi di hadapan orang-orang, akan tetapi menunggu waktu dan tempat yang tepat untuk mengekspresikan emosinya dengan cara yang bisa diterima oleh lingkungan ${ }^{[6]}$. Dari pengertian tersebut, dapat disimpulkan bahwa kematangan emosi anak merupakan kemampuan anak dalam mengendalikan, memahami dorongan perasaan dan pikiran, serta mengekspresikan rasa nyaman dan ketidaknyaman dengan baik ketika berada dalam kondisi kritis yang dihadapinya.

Kematangan emosi yang baik didapat ketika anak telah memperoleh perkembangan emosi yang sebanding dengan tahap usianya. Karakteristik kompetensi emosi di usia anak-anak yang berkaitan dengan situasi sosial, meliputi:

1) Pemahaman keadaan emosi yang dialami. Anak dapat memilah apakah sedang sedih atau gelisah;

2) Mengetahui emosi orang lain. Anak memahami bahwa orang lain sedang merasa sedih atau takut;

3) Mengungkapkan kata yang berkaitan dengan emosi yang sesuai pada situasi sosial dan budaya tertentu. Anak dapat membayangkan kondisi sosial yang sesuai dalam budaya tertentu ketika mengalami kesulitan;

4) Kepekaan empatik dan simpatik terhadap pengalaman emosional orang lain. Anak mampu bersikap sensitif kepada orang lain yang merasakan emosi negatif;

5) Memahami kondisi emosional tidak selalu menampakkan dengan ekspresi. Anak dapat menyadari bahwa seseorang yang merasa marah bisa mengatur ekspresi emosinya sehingga terlihat netral;

6) Coping adaptif terhadap emosi negatif menggunakan strategi self-regulatory yang dapat meminimalisir durasi dan intensitas dari emosi. Artinya anak mengurangi kemarahan dengan menghindari situasi yang mengganggu dan melibatkan diri pada aktivitas yang dapat membuat dirinya bisa melepaskan pikiran terhadap situasi yang menganggu;

7) Menyadari bahwa ekspresi emosi mewakili peranan dalam hubungan interpersonal. Artinya anak dapat mengetahui bahwa terlalu sering mengekspresikan kemarahan pada seorang teman dapat mengganggu hubungan pertemanan.;

8) Memandang bahwa kondisi emosi pada diri adalah cara untuk mengatur emosinya. Anak dianggap bahwa dirinya mampu melakukan coping secara efektif terhadap stress ${ }^{[15]}$. 
Ada beberapa faktor yang memengaruhi perkembangan emosi anak, yaitu:

1) Pola asuh. Keluarga merupakan tempat yang awal bagi anak untuk belajar dan berinteraksi. Perbedaan pola asuh orang tua dapat berpengaruh terhadap perkembangan emosi anak. Cara orang tua dalam mendidik dan memperlakukan anak mengakibatkan emosi yang mendalam bagi individu;

2) Temperamen. Setiap individu mempunyai tingkat emosi yang berbeda-beda. Temperamen sudah ada dalam diri individu sejak lahir dan merupakan bagian dari genetik yang memiliki kekuatan selama rentang kehidupan;

3) Jenis kelamin. Perbedaan jenis kelamin juga dapat berpengaruh terhadap adanya karakteristik emosi yang berbeda;

4) Usia perkembangan dengan bertambahnya usia. Kematangan emosi dipengaruhi oleh tingkat pertumbuhan dan kematangan secara fisik seseorang;

5) Perubahan fisik. Pertumbuhan yang cepat juga memengaruhi kondisi emosi seseorang. Tidak semua anak dapat menerima perubahan kondisi tubuhnya. Hormon yang berfungsi menyebabkan rangsangan di dalam tubuh anak dan dapat menimbulkan masalah dalam perkembangan emosinya;

6) Interaksi dengan teman sebaya. Anak biasanya membangun hubungan interaksi dengan teman sebayanya. Tidak jarang dalam berinteraksi timbul menimbulkan konflik atau gangguan emosi pada anak ${ }^{[2]}$.

Terdapat faktor penting yang berkaitan dengan kematangan emosi siswa selain faktor-faktor di atas, yaitu kematangan kognitif (mental), di mana anak memahami makna baru yang sebelumnya tidak dipahami, memfokuskan perhatian dalam jangka waktu yang lama, dan memfokuskan ketegangan emosi untuk hal-hal tertentu. Proses belajar juga memengaruhi respon emosional anak. Proses belajar dibagi tiga yaitu, proses belajar mencoba-coba (trial and error). Proses ini didasari oleh pengalaman yang sudah lampau. Proses belajar ini memengaruhi aspek respon dari bentuk emosi, sehingga membuat anak mendapatkan cara melampiaskan emosi yang sangat memuaskan bagi dirinya. Kedua adalah proses belajar secara imitasi. Proses belajar secara imitasi dilakukan anak dengan cara melihat orang-orang di sekitarnya beraksi terhadap keadaan tertentu. Proses ini memengaruhi rangsangan dan respon bentuk emosi. Emosi akan menjalar dari satu individu ke individu yang lain. Pada proses ini, anak akan menerima macam-macam stimulus yang diberi respon emosional dan respon apa saja yang diberikan terhadap stimulus tersebut. Penularan emosi dipengaruhi oleh ketergantungan, sugestibilitas, dan juga penerimaan lingkungan sosial terhadap pola emosi anak tersebut. Terakhir, proses belajar secara pengondisian (conditioning). Emosi yang diperoleh dari proses belajar ini meluas pada stimulusstimulus sejenis melalui proses pengelompokan. Proses belajar ini terjadi secara ringan, mudah, dan cepat pada masa anak-anak awal, sebab di usia itu, anak belum mempunyai kemampuan untuk menalar dan pengalaman untuk menilai suatu kondisi sekitar secara teliti dan menyadari ketidakrasionalan respon emosi tersebut ${ }^{[18]}$.

\section{METODE PENELITIAN}

Penelitian ini menggunakan metode kualitatif fenomenologi. Metode kualitatif adalah metode yang dilakukan secara mendalam, di mana peneliti secara langsung terlibat di lapangan, menuliskan secara teliti dengan apa yang terjadi dan apa yang 
dilihat, melakukan analisis reflektif pada dokumen-dokumen yang dijumpai di lapangan, dan membuat laporan penelitian secara terperinci ${ }^{[21]}$. Penelitian fenomenologi menggambarkan makna pengalaman subjek akan fenomena yang sedang diteliti. Menurut Husserl, fenomenologi dapat disebut sebagai pengalaman subjektif atau pengalaman fenomenologikal, yaitu suatu studi tentang kesadaran dari perspektif pokok dari seseorang. Oleh sebab itu, pemahaman tentang fenomenologis berupaya untuk menafsirkan arti kejadian dan kaitan-kaitannya terhadap orang yang berada dalam kondisi tertentu ${ }^{[9]}$. Metode yang benar-benar ilmiah adalah metode yang membuat fenomena sesuai dengan realita yang sesungguhnya. Pengambilan subjek pada penelitian ini menggunakan teknik purposive sampling. Teknik purposive sampling merupakan cara pengambilan sampel sumber data dengan karakteristik tertentu ${ }^{[21]}$. Karakteristik subjek dalam penelitian ini adalah siswa kelas B di TK swasta di Sidoarjo yang memiliki pencapaian perkembangan kognitif Berkembang Sangat Baik (BSB) dengan jumlah terbanyak dalam penilaian di rapot.

Teknik pengumpulan data yang digunakan adalah metode wawancara, observasi partisipatif, dan dokumentasi. Wawancara merupakan bertemunya dua orang yang saling bertukar informasi dan ide dengan tanya jawab, sehingga dapat diinterpretasikan makna dalam suatu topik tertentu ${ }^{[22]}$. Jenis wawancara yang digunakan peneliti adalah wawancara semi tertruktur. Wawancara semi terstruktur bertujuan untuk mendapatkan persoalan dengan lebih terbuka, di mana seseorang yang dijadikan sebagai informan dimintia pendapat dan ide-idenya. Peneliti perlu mendengar secara teliti dan menuliskan apa yang dikatakan oleh informan ${ }^{[21]}$. Wawancara pada penelitian ini dilakukan kepada 3 siswa kelas B yaitu SA, TT, dan RN beserta significant other yaitu orang tua masing-masing siswa, yang berinisial NL, $\mathrm{S}$, dan NC, dan satu guru pengajar yaitu LH. Untuk memperoleh informasi yang sesuai, berikut pedoman wawancara yang difokuskan pada aspek kematangan emosi:

1) Pemahaman keadaan emosi yang dialami;

2) Mengetahui emosi orang lain;

3) Dapat mengungkapkan kata yang berkaitan dengan emosi;

4) Kepekaan empatik dan simpatik terhadap pengalaman emosi orang lain;

5) Memandang keadaan emosi diri sebagai cara mengatur emosi;

6) Memahami kondisi emosional tidak selalu menampakkan dengan ekspresi;

7) Menyadari ekspresi emosi mewakili peranan dalam berhubungan interpersonal;

8) Coping adaptif terhadap emosi negatif dengan menggunakan strategi self-regulatory yang dapat mengurangi durasi dan intensitas dari emosi ${ }^{[21]}$.

Selain wawancara, peneliti juga melakukan observasi partisipatif. Peneliti melihat apa yang dilakukan, mendengarkan apa yang dikatakan, dan ikut serta dalam kegiatan yang dilakukan subjek ${ }^{[21]}$. Salah satu teknik observasi yang dilakukan peneliti adalah teknik event sampling. Teknik ini hanya mengamati perilaku-perilaku tertentu pada situasi saat itu. Observasi dilakukan pada tiga subjek yang sesuai dengan kriteria dengan melihat pola-pola emosi yang muncul, yaitu takut, malu (embarrassment), kekhawatiran, kecemasan, marah, iri hati, sedih, rasa ingin tahu, kesukaan/ kesenangan, dan kasih sayang. Penelitian dilakukan di TK swasta di Sidoarjo. Peneliti ikut serta dalam kegiatan di sekolah sebagai guru pendamping selama pembelajaran berlangsung dengan periode yang telah ditentukan. Terakhir adalah dokumen, yaitu 
catatan kejadian yang telah berlalu. Dokumen dapat dilihat melalui tulisan, gambar, atau karya-karya monumental dari seseorang. Dokumentasi penelitian ini menggunakan buku penilaian hasil belajar siswa (rapor) dengan melihat aspek perkembangan kognitif dan emosi.

Untuk menguji keabsahan data, peneliti menggunakan kredibilitas. Terdapat beberapa cara dalam uji kredibilitas, atau kepercayaan terhadap data hasil penelitian kualitatif, salah satunya triangulasi. Triangulasi adalah teknik pengumpulan data yang bersifat memadukan beberapa teknik pengumpulan data dan sumber yang sudah didapatkan ${ }^{[21]}$. Metode inilah yang akan digunakan oleh peneliti. Jenis triangulasi yang akan digunakan adalah triangulasi sumber (sumber informasi terdiri dari siswa, guru dan orang tua siswa ) dan triangulasi teknik (teknik wawancara, observasi partisipatif dan dokumentasi dari hasil rapot siswa). Teknik analisis penelitian ini adalah teknik analisis data dari Miles dan Huberman. Keduanya menyatakan bahwa aktivitas dalam menganalisis data kualitatif dilakukan secara interaktif dan berlangsung secara berkesinambungan sampai selesai, sehingga datanya sudah lengkap ${ }^{[21]}$. Ada beberapa langkah untuk menganalisis data dengan model Miles dan Huberman Pertama, data reduction (reduksi data). Mereduksi data berarti meringkas dan memilih hal-hal yang substansial, memfokuskan pada hal-hal yang paling inti, dan mencari pokok pikiran untuk memudahkan pengumpulan data selanjutnya ${ }^{[21]}$. Dalam penelitian ini, setelah melakukan pengumpulan data, peneliti mereduksi data-data yang terkait dengan aspek kematangan emosi siswa TK B di TK swasta di Sidoarjo untuk digolongkan dalam setiap permasalahan untuk kemudian ditarik kesimpulan. Kedua. data display (penyajian data). Penyajian data dilakukan dengan teks yang bersifat menguraikan suatu rangkaan kejadian dan didukung dengan grafik untuk lebih mempermudah pemahaman data yang ditampilkan. Selanjutnya, conclusion drawing atau verification. Kesimpulan dari sebuah penelitian kualitatif merupakan hasil temuan baru yang belum pernah ada ${ }^{[21]}$. Dengan demikian, kesimpulan dalam penelitian ini dapat menjawab rumusan masalah yang diteliti.

\section{HASIL DAN DISKUSI}

Hasil dalam penelitian ini menunjukkan masing-masing gambaran subjek yang memiliki tingkat kematangan emosi yang baik.

Tabel 1. Matrik Identitas Subjek

\begin{tabular}{cccccc}
\hline $\begin{array}{c}\text { Unit } \\
\text { Analisis }\end{array}$ & Inisial & $\begin{array}{c}\text { Jenis } \\
\text { Kelamin }\end{array}$ & Usia & Kelas & Sekolah \\
\hline Subjek 1 & SA & Laki-laki & 6 tahun & $\begin{array}{c}\text { TK B } \\
1\end{array}$ & $\begin{array}{c}\text { TK ABA 3 } \\
\text { Sidoarjo }\end{array}$ \\
\hline Subjek 2 & TT & Perempuan & 6 tahun & $\begin{array}{c}\text { TK B } \\
2\end{array}$ & $\begin{array}{c}\text { TK ABA 3 } \\
\text { Sidoarjo }\end{array}$ \\
\hline Subjek3 & RN & Laki-laki & 6 tahun & $\begin{array}{c}\text { TK B } \\
3\end{array}$ & $\begin{array}{c}\text { TK ABA 3 } \\
\text { Sidoarjo }\end{array}$ \\
\hline
\end{tabular}

Gambaran subjek dalam penelitian ini merupakan seorang siswa dan siswi TK B swasta di Sidoarjo. Masing-masing subjek berasal dari kelas yang berbeda-beda, 
yaitu subjek 1 dari kelas B1, subjek 2 dari kelas B2, dan subjek 3 dari kelas B3. Ketiga subjek berusia 6 tahun. Subjek 1 dan 3 berjenis kelamin laki-laki, sedangkan subjek 2 berjenis kelamin perempuan.

Kematangan emosi adalah kemampuan setiap manusia untuk mengutarakan dan mengekspresikan emosinya dengan baik untuk hal yang berguna tanpa menghiraukan perasaan yang ada dalam dirinya. Aspek-aspek dalam kematangan emosi antara lain memahami keadaan emosi yang dialami, mengetahui emosi orang lain, mengungkapkan kata yang berkaitan dengan emosi, kepekaan empatik dan simpatik terhadap pengalaman emosional orang lain, memahami kondisi emosional dengan tidak selalu menampakkan dengan ekspresi, coping adaptif terhadap emosi negatif menggunakan strategi self-regulatory yang dapat meminimalisir durasi dan intensitas dari emosi, menyadari bahwa ekspresi emosi mewakil peranan dalam hubungan interpersonal, dan memandang bahwa kondisi emosi pada diri adalah cara untuk mengatur emosinya. Aspek kematangan emosi pada 3 siswa di TK swasta di Sidoarjo ditunjukkan pada tabel 2 di bawah ini.

Tabel 2. Aspek Kematangan Emosi

\begin{tabular}{|c|c|c|c|}
\hline $\begin{array}{c}\text { Aspek } \\
\text { Kematangan } \\
\text { Emosi }\end{array}$ & Subjek I & Subjek II & Subjek III \\
\hline $\begin{array}{l}\text { Pemahaman } \\
\text { keadaan emosi } \\
\text { yang dialami }\end{array}$ & $\begin{array}{l}\text { Mampu } \\
\text { memahami dan } \\
\text { membedakan } \\
\text { emosi yang } \\
\text { dialami seperti } \\
\text { ketika senang, } \\
\text { marah, sedih, } \\
\text { takut dan kasih } \\
\text { saying }\end{array}$ & $\begin{array}{l}\text { Mampu } \\
\text { memahami dan } \\
\text { membedakan } \\
\text { emosi yang } \\
\text { dialami seperti } \\
\text { ketika senang, } \\
\text { sedih, marah, } \\
\text { takut dan } \\
\text { khawatir }\end{array}$ & $\begin{array}{lr}\text { Mampu } \\
\text { memahami dan } \\
\text { membedakan } \\
\text { emosi yang } \\
\text { dialami seperti } \\
\text { ketika marah, } \\
\text { sedih, } \\
\text { sayang } \\
\text { senang }\end{array}$ \\
\hline $\begin{array}{l}\text { Mengetahui } \\
\text { emosi orang lain }\end{array}$ & $\begin{array}{l}\text { Mampu } \\
\text { mengetahui } \\
\text { emosi orang lain } \\
\text { ketika marah dan } \\
\text { sedih dengan } \\
\text { melihat ekspresi } \\
\text { wajah orang lain } \\
\text { seperti menangis } \\
\text { dan diam (marah) }\end{array}$ & $\begin{array}{l}\text { Mampu } \\
\text { mengetahui } \\
\text { emosi orang lain } \\
\text { ketika melihat } \\
\text { ekspresi wajah } \\
\text { dan ungkapan } \\
\text { bahasa orang lain } \\
\text { seperti nada } \\
\text { marah(berbicara } \\
\text { dengan nangi), } \\
\text { yang tinggis } \\
\text { sedih (menangis), } \\
\text { iba (anak sedang } \\
\text { mengemis) dan } \\
\text { kebingungan }\end{array}$ & $\begin{array}{l}\text { Mampu } \\
\text { mengetahui } \\
\text { emosi orang lain } \\
\text { dengan eskpresi } \\
\text { wajah dan } \\
\text { perilaku orang } \\
\text { lain seperti ketika } \\
\text { sedih menyendiri } \\
\text { (tidak memiliki } \\
\text { teman dan } \\
\text { menangis), dan } \\
\text { lesu (kelelahan) }\end{array}$ \\
\hline Mengungkapkan & Mampu & Mampu & Mampu \\
\hline
\end{tabular}




\begin{tabular}{|c|c|c|c|}
\hline kata yang & mengungkapkan & mengungkapkan & mengungkapkan \\
\hline $\begin{array}{l}\text { berkaitan dengan } \\
\text { emosi }\end{array}$ & $\begin{array}{l}\text { kata-kata yang } \\
\text { berhubungan } \\
\text { dengan emosi } \\
\text { secara verbal } \\
\text { ketika sedang } \\
\text { marah, khawatir, } \\
\text { perasaan bersalah }\end{array}$ & $\begin{array}{l}\text { kata-kata yang } \\
\text { berhubungan } \\
\text { dengan emosi } \\
\text { secara verbal } \\
\text { ketika sedang } \\
\text { marah, kesal, iba, } \\
\text { sedih dan } \\
\text { kegembiraan }\end{array}$ & $\begin{array}{lr}\text { kata-kata yang } \\
\text { berhubungan } \\
\text { dengan emosi } \\
\text { secara verbal } \\
\text { ketika sedang } \\
\text { marah, gembira, } \\
\begin{array}{l}\text { kesedihan dan } \\
\text { ketakutan }\end{array}\end{array}$ \\
\hline $\begin{array}{l}\text { Kepekaan } \\
\text { empatik dan } \\
\text { simpatik terhadap } \\
\text { pengalaman } \\
\text { emosional orang } \\
\text { lain }\end{array}$ & $\begin{array}{l}\text { Memiliki } \\
\text { kepekaan } \\
\text { terhadap situasi } \\
\text { disekitarnya dan } \\
\text { mampu } \\
\text { merasakan emosi } \\
\text { negatif orang lain } \\
\text { dengan } \\
\text { menunjukkan } \\
\text { sikap empatik } \\
\text { dan simpatik } \\
\text { seperti } \\
\text { menghibur } \\
\text { teman, } \\
\text { memberikan } \\
\text { ketenangan, } \\
\text { berbagi dan } \\
\text { meminta maaf } \\
\text { ketika melakukan } \\
\text { kesalahan }\end{array}$ & $\begin{array}{l}\text { Memiliki } \\
\text { kepekaan } \\
\text { terhadap situasi } \\
\text { disekitarnya dan } \\
\text { mampu } \\
\text { merasakan emosi } \\
\text { negatif orang lain } \\
\text { dengan } \\
\text { menunjukkan } \\
\text { sikap empatik } \\
\text { dan simpatik } \\
\text { seperti mengajak } \\
\text { bermain bersama, } \\
\text { menenangkan, } \\
\text { berbagi dan } \\
\text { membantu orang } \\
\text { lain yang } \\
\text { mengalami } \\
\text { kesulitan }\end{array}$ & $\begin{array}{l}\text { Memiliki } \\
\text { kepekaan } \\
\text { terhadap situasi } \\
\text { disekitarnya dan } \\
\text { mampu } \\
\text { merasakan emosi } \\
\text { negatif orang lain } \\
\text { senan } \\
\text { menunjukkan } \\
\text { sikap empatik } \\
\text { dan simpatik } \\
\text { seperti dan } \\
\text { menenangkan, } \\
\text { melerai } \\
\text { membantu orang } \\
\text { lain } \\
\text { mengalami yang } \\
\text { kesulitan }\end{array}$ \\
\hline $\begin{array}{l}\text { Memahami } \\
\text { kondisi emosional } \\
\text { tidak selalu } \\
\text { menampakkan } \\
\text { dengan ekspresi }\end{array}$ & $\begin{array}{l}\text { Mencoba untuk } \\
\text { tidak } \\
\text { menampakkan } \\
\text { keadaan emosi } \\
\text { yang dialami } \\
\text { dengan } \\
\text { memperlihatkan } \\
\text { ekspresi wajah } \\
\text { seperti ketika } \\
\text { mendapatkan } \\
\text { perilaku agresi } \\
\text { fisik dari teman } \\
\text { berusaha untuk } \\
\text { menutupi } \\
\text { kesedihannya } \\
\text { (menangis) }\end{array}$ & $\begin{array}{l}\text { Mencoba untuk } \\
\text { tidak } \\
\text { menampakkan } \\
\text { keadaan emosi } \\
\text { yang dialami } \\
\text { dengan } \\
\text { memperlihatkan } \\
\text { ekspresi wajah } \\
\text { seperti ketika } \\
\text { teman merebut } \\
\text { mainan dan adik } \\
\text { tidak sengaja } \\
\text { dirusakkan } \\
\text { berusaha } \\
\text { menutupi } \\
\text { kemarahan }\end{array}$ & $\begin{array}{l}\text { Mencoba untuk } \\
\text { tidak } \\
\text { menampakkan } \\
\text { keadaan emosi } \\
\text { yang dialami } \\
\text { dengan } \\
\text { memperlihatkan } \\
\text { ekspresi wajah } \\
\text { seperti ketika } \\
\text { mendapatkan } \\
\text { perilaku agresi } \\
\text { verbal dari teman } \\
\text { dan takut (tidak } \\
\text { nyaman) } \\
\text { berusahan untuk } \\
\text { menutupi }\end{array}$ \\
\hline
\end{tabular}




\begin{tabular}{|c|c|c|c|}
\hline & & (membentak) & $\begin{array}{l}\text { kemarahan dan } \\
\text { kesedihan }\end{array}$ \\
\hline $\begin{array}{l}\text { Coping adaptif } \\
\text { terhadap emosi } \\
\text { negatif } \\
\text { menggunakan } \\
\text { strategi self- } \\
\text { regulatory yang } \\
\text { dapat } \\
\text { meminimalisir } \\
\text { durasi dan } \\
\text { intensitas dari } \\
\text { emosi }\end{array}$ & $\begin{array}{l}\text { Mampu } \\
\text { meminimalisir } \\
\text { intensitas dan } \\
\text { durasi emosi } \\
\text { negatif dengan } \\
\text { strategi self } \\
\text { regulatory } \\
\text { menghindari } \\
\text { situasi yang } \\
\text { bermasalah, } \\
\text { bermain sendiri, } \\
\text { tidur dan } \\
\text { mencoba bersabar } \\
\text { dengan } \\
\text { menenangkan } \\
\text { diri }\end{array}$ & \begin{tabular}{lr}
\multicolumn{2}{l}{ Mampu } \\
meminimalisir \\
intensitas dan \\
durasi emosi \\
negatif & dengan \\
strategi & self \\
regulatory & seperti \\
membeli & dan \\
memakan & es \\
krim, & \\
menghindari \\
situasi \\
bermasalah dan \\
bernafas panjang \\
lalu menceritakan \\
perasaannya
\end{tabular} & $\begin{array}{l}\text { Mampu } \\
\text { meminimalisir } \\
\text { intensitas dan } \\
\text { durasi emosi } \\
\text { negatif dengan } \\
\text { strategi self } \\
\text { regulatory seperti } \\
\text { membaca ayat } \\
\text { kursi, } \\
\text { mengucapkan } \\
\text { hadist tidak boleh } \\
\text { marah, tidur dan } \\
\text { bermain sendiri }\end{array}$ \\
\hline $\begin{array}{l}\text { Menyadari bahwa } \\
\text { ekspresi emosi } \\
\text { mewakil peranan } \\
\text { dalam hubungan } \\
\text { interpersonal }\end{array}$ & $\begin{array}{l}\text { Memahami setiap } \\
\text { emosi yang } \\
\text { dimunculkan } \\
\text { dapat } \\
\text { memengaruhi } \\
\text { hubungan } \\
\text { interpersonal } \\
\text { seperti apabila } \\
\text { selalu berbuat } \\
\text { marah maka } \\
\text { tidak memiliki } \\
\text { teman }\end{array}$ & $\begin{array}{l}\text { Memahami setiap } \\
\text { emosi yang } \\
\text { dimunculkan } \\
\text { dapat } \\
\text { memengaruhi } \\
\text { hubungan } \\
\text { interpersonal } \\
\text { seperti apabila } \\
\text { suka marah, pelit } \\
\text { dapat mengganggu } \\
\text { pertemanan }\end{array}$ & $\begin{array}{l}\text { Memahami setiap } \\
\text { emosi yang } \\
\text { dimunculkan } \\
\text { dapat } \\
\text { memengaruhi } \\
\text { hubungan } \\
\text { interpersonal } \\
\text { seperti apabila } \\
\text { marah-marah } \\
\text { maka tidak } \\
\text { memiliki teman } \\
\text { dan berusaha } \\
\text { untuk berbuat } \\
\text { baik teman } \\
\text { memiliki temar } \\
\text { banyak }\end{array}$ \\
\hline $\begin{array}{l}\text { Memandang } \\
\text { bahwa kondisi } \\
\text { emosi pada diri } \\
\text { adalah cara untuk } \\
\text { mengatur } \\
\text { emosinya }\end{array}$ & $\begin{array}{l}\text { Mampu } \\
\text { melakukan cara } \\
\text { mengatur emosi } \\
\text { dan coping secara } \\
\text { efektif dengan } \\
\text { menghindari } \\
\text { situasi yang } \\
\text { bermasalah dan } \\
\text { mengucapkan } \\
\text { hadist tidak boleh } \\
\text { marah ketika }\end{array}$ & $\begin{array}{l}\text { Mampu } \\
\text { melakukan cara } \\
\text { mengatur emosi } \\
\text { dan coping secara } \\
\text { efektif dengan } \\
\text { menghindari } \\
\text { situasi yang } \\
\text { bermasalah dan } \\
\text { membeli } \\
\text { makanan yang } \\
\text { disukai }\end{array}$ & $\begin{array}{l}\text { Mampu } \\
\text { melakukan cara } \\
\text { mengatur emosi } \\
\text { dan coping secara } \\
\text { efektif dengan } \\
\text { mengucapkan } \\
\text { hadist tidak boleh } \\
\text { marah ketika } \\
\text { akan marah dan } \\
\text { menjauhi teman } \\
\text { yang berperilaku }\end{array}$ \\
\hline
\end{tabular}


Berdasarkan pemaparan di atas, ditemukan bahwa kematangan emosi pada siswa TK B memiliki kematangan kognitif berberagam bentuknya. Bentuk kematangan emosi yang dimunculkan berbeda-beda, namun ada pula yang sama dan ketiga subjek memunculkan masing-masing aspek kematangan emosi. Ketiga anak telah memperoleh perkembangan emosi yang sebanding dengan tahap usianya. Emosi anak dikatakan kompeten apabila dapat mengembangkan keterampilan yang berkaitan dengan situasi sosial ${ }^{[15]}$.

Ketiga subjek mampu menggambarkan pemahaman tentang keadaan emosi yang dialami, seperti marah, senang, takut, sedih, khawatir, dan kasih sayang. Pada aspek lain, yaitu mengetahui emosi orang lain, ketiga subjek mampu mengetahui emosi yang dialami orang lain dengan pengamatan meskipun setiap subjek berbedabeda dalam mengekspresikannya, seperti melalui ekspresi wajah, ungkapan bahasa, dan perilaku orang lain.

Pada aspek menggunakan kata-kata yang berhubungan dengan emosi yang sesuai pada situasi sosial dan budaya tertentu, menunjukkan ketiga subjek dapat mengungkapkan kemarahannya saat diganggu dan dibohongi. Mereka juga mengakui kesalahan ketika bersalah, mengungkapkan kegembiraan dengan bercerita pada orang tua, dan menceritakan kegelisahan dengan berdoa. Anak-anak usia prasekolah dapat membicarakan emosi mereka dan membedakan perasaan orang lain. Mereka juga memahami bahwa emosi berhubungan dengan pengalaman dan hasrat ${ }^{[12]}$.

Pada aspek kepekaan empatik dan simpatik, terhadap pengalaman emosinal orang lain. Ketiga subjek dapat menunjukkan kepekaan emosi negatif yang dirasakan orang lain dengan perilaku empati dan simpati seperti dengan menghibur, menenangkan temannya yang sedih akibat orang tua yang memarahinya dengan mengatakan bahwa orang tua marah karena sayang dengan anaknya, selalu berbagi dengan orang yang membutuhkan, dan meminta maaf ketika melakukan kesalahan kepada temannya. Mereka juga mengajak bermain bersama ketika melihat temannya sedang sendiri, mencoba menenangkan ketika temannya menangis, berbagi makanan, dan memberi uang kepada orang yang membutuhkan. Papalia menyatakan bahwa pemahaman emosi memungkinkan anak untuk mengontrol dan menunjukkan perasaan diri serta menjadi lebih peka terhadap perasaan orang lain ${ }^{[12]}$.

Pada aspek memahami kondisi emosional, tampak pada ketiga subjek ketika dirinya mendapat agresi fisik dengan menunjukkan perilaku diam, mengalah atau tidak membalas perbuatan temannya, dan memaafkan. Ketiga subjek mengurangi kemarahan dengan menghindari hal yang dapat memancing emosi. Salah satu cara yang mereka lakukan adalah dengan mencari mainan lain dan bermain sendiri, tidak membalas perbuatan buruk orang lain, dan mencoba untuk menjauh dari sumber masalah.

Pada aspek menyadari bahwa ekspresi emosi mewakili peranan dalam hubungan interpersonal, ketiga subjek menyadari bahwa ekspresi ataupun perilaku negatif yang dimunculkan dapat berpengaruh pada hubungan pertemanan. Mereka cenderung berbuat baik ketika bermain untuk menjaga hubungan antar teman. Pada aspek memandang bahwa kondisi emosi pada diri adalah cara untuk mengatur 
emosinya, ketiga subjek menunjukkan bahwa dirinya mampu mengatur emosi dengan tidak menyerang atau membalas perilaku buruk orang lain, tetapi lebih menghindari situasi yang dapat menyebabkan permasalahan, dan mencoba menenangkan diri dengan cara islami seperti mengingat hadis yang diajarkan oleh orang tua dan guru di sekolah.

Kematangan emosi dipengaruhi oleh beberapa faktor, di antaranya pola asuh orang tua, temperamen, jenis kelamin, usia perkembangan kematangan emosi yang sejalan dengan bertambahnya usia, perubahan jasmani, dan interaksi dengan teman sebaya. Hal ini juga terjadi pada 3 siswa di TK swasta di Sidoarjo. Banyak faktor yang memengaruhi kematangan emosi mereka. Faktor-faktor tersebut dapat dilihat dalam tabel di bawha ini.

\section{Tabel 3. Faktor yang Memengaruhi Kematangan Emosi}

Faktor yang memengaruhi kematangan Subjek I Subjek II Subjek III emosi

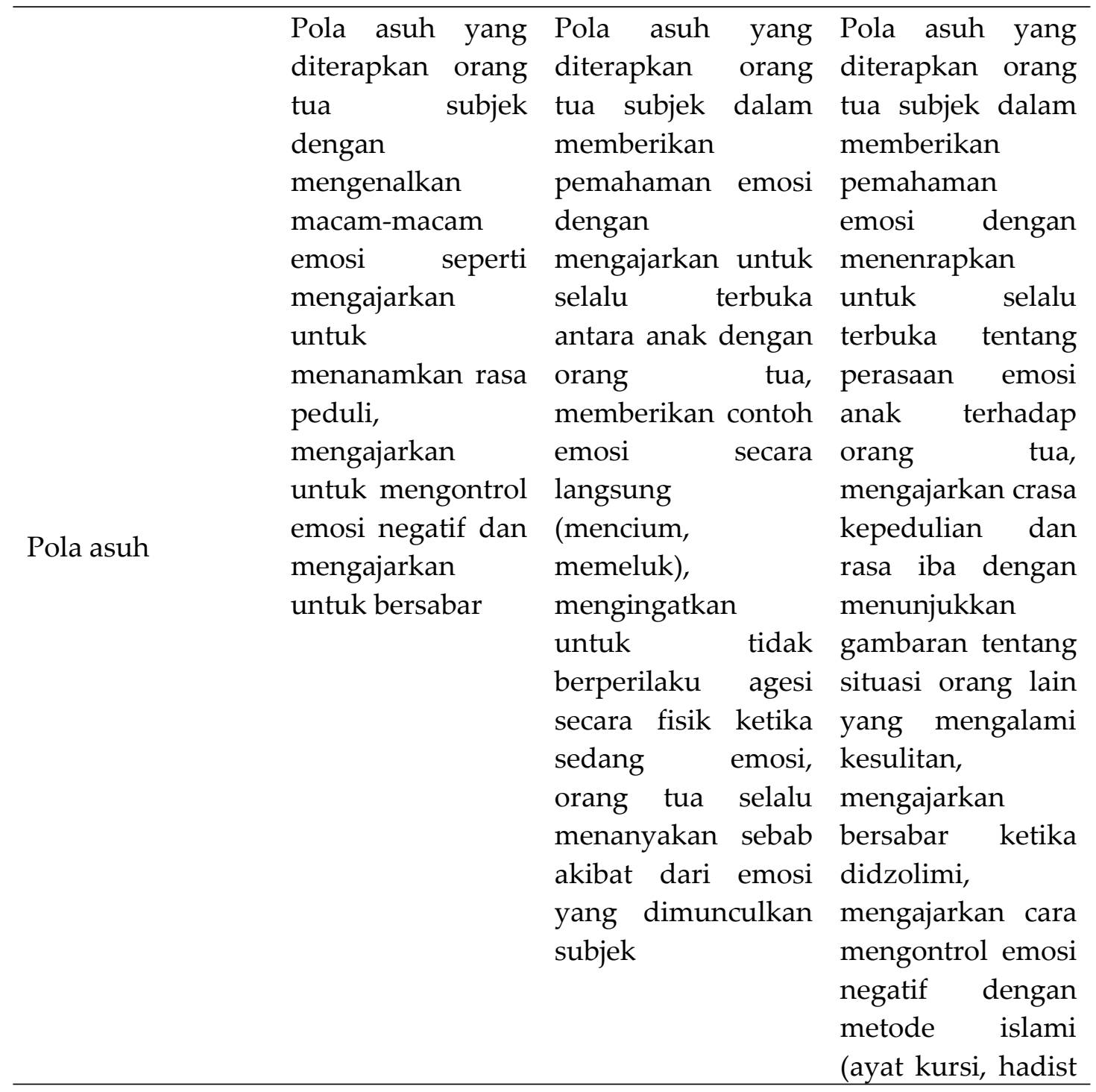




\begin{tabular}{|c|c|c|c|}
\hline & & & $\begin{array}{l}\text { tidak } \\
\text { marah) }\end{array}$ \\
\hline Temperamen & $\begin{array}{l}\text { Subjek anak yang } \\
\text { mudah diatur, } \\
\text { mudah menerima } \\
\text { hal baru, mudah } \\
\text { beradaptasi } \\
\text { dengan } \\
\text { lingkungan, } \\
\text { makanan dan } \\
\text { orang baru dan } \\
\text { selalu tenang } \\
\text { dalam } \\
\text { menghadapi } \\
\text { sesuatu }\end{array}$ & $\begin{array}{l}\text { Subjek anak yang } \\
\text { memiliki pendirian } \\
\text { kuat, mau belajar } \\
\text { akan hal baru, } \\
\text { mudah diatur, } \\
\text { kebiasaan tidur, } \\
\text { makan dan buang } \\
\text { air besar teratur, } \\
\text { kreatif, dan mudah } \\
\text { beradaptasi dengan } \\
\text { lingkungan dan } \\
\text { orang baru }\end{array}$ & $\begin{array}{l}\text { Subjek cenderung } \\
\text { sulit beradaptasi } \\
\text { dengan hal baru, } \\
\text { mudah } \\
\text { dipengaruhi } \\
\text { sehingga timbul } \\
\text { perasaan marah } \\
\text { dan kesal, rewel, } \\
\text { takut dengan } \\
\text { orang yang tidak } \\
\text { dikenal, } \\
\text { cenderung } \\
\text { berhati-hati } \\
\text { dengan orang } \\
\text { asing. } \\
\text { Perhatiannya sulit } \\
\text { dialihkan }\end{array}$ \\
\hline Jenis kelamin & $\begin{array}{l}\text { Jenis kelamin laki- } \\
\text { laki }\end{array}$ & $\begin{array}{l}\text { Jenis kelamin } \\
\text { perempuan }\end{array}$ & $\begin{array}{l}\text { Jenis kelamin laki- } \\
\text { laki }\end{array}$ \\
\hline $\begin{array}{l}\text { Usia } \\
\text { perkembangan } \\
\text { dengan } \\
\text { bertambahnya } \\
\text { usia }\end{array}$ & Usia 6 tahun & Usia 6 tahun & Usia 6 tahun \\
\hline Perubahan fisik & $\begin{array}{lr}\text { Lingkar } & \text { kepala, } \\
\text { berat badan dan } \\
\text { tinggi } & \text { badan } \\
\text { sesuai } & \text { dengan } \\
\text { standart } & \text { tingkat } \\
\text { usia } & \end{array}$ & $\begin{array}{l}\text { Lingkar kepala, } \\
\text { berat badan dan } \\
\text { tinggi badan sesuai } \\
\text { dengan standart } \\
\text { tingkat usia }\end{array}$ & $\begin{array}{lr}\text { Lingkar } & \text { kepala, } \\
\text { berat badan dan } \\
\text { tinggi } \\
\text { sesuai } \\
\text { standart dengan } \\
\text { usia }\end{array}$ \\
\hline $\begin{array}{l}\text { Interaksi dengan } \\
\text { teman sebaya }\end{array}$ & $\begin{array}{l}\text { Subjek } \\
\text { berinteraksi } \\
\text { dengan teman } \\
\text { sebaya dapat } \\
\text { memunculkan } \\
\text { emosi pada diri } \\
\text { Subjek dan teman } \\
\text { sebaya }\end{array}$ & $\begin{array}{l}\text { Dalam berinteraksi } \\
\text { dengan teman } \\
\text { sebaya, Subjek juga } \\
\text { dapat merasakan } \\
\text { emosi teman sebaya }\end{array}$ & \begin{tabular}{lr}
\multicolumn{2}{l}{ Dengan } \\
berinteraksi \\
dengan teman \\
sebaya membuat \\
Subjek & dapat \\
mengetahui dan \\
peka terhadap \\
emosi \\
sebaya
\end{tabular} \\
\hline $\begin{array}{l}\text { Kematangan } \\
\text { kognitif (mental) }\end{array}$ & $\begin{array}{lr}\text { Dengan } & \text { memiliki } \\
\text { daya } & \text { pemikiran } \\
\text { dan } & \text { banyak }\end{array}$ & $\begin{array}{l}\text { Subjek memiliki } \\
\text { kemampuan untuk } \\
\text { mengkategorisasi, }\end{array}$ & $\begin{array}{l}\text { Subjek berusaha } \\
\text { bertanggung } \\
\text { jawab, aktif dan }\end{array}$ \\
\hline
\end{tabular}




\begin{tabular}{|c|c|c|c|}
\hline & $\begin{array}{l}\text { gagasan Subjek } \\
\text { memiliki } \\
\text { kemampuan } \\
\text { dalam mengatasi } \\
\text { masalah yang } \\
\text { dihadapi }\end{array}$ & $\begin{array}{lr}\text { bereksplorasi, aktif } \\
\text { dan berinisiatif } \\
\text { untuk melakukan } \\
\text { kegiatan baru, } \\
\text { memiliki } & \\
\text { kemampuan } & \\
\text { berusaha untuk } \\
\text { memecahkan } \\
\text { masalah yang } \\
\text { dihadapi }\end{array}$ & $\begin{array}{l}\text { eksploratif, } \\
\text { memiliki } \\
\text { kemampuan } \\
\text { untuk } \\
\text { mengkategorisasi }\end{array}$ \\
\hline $\begin{array}{l}\text { Proses belajar } \\
\text { mencoba-coba }\end{array}$ & $\begin{array}{l}\text { Subjek mencoba } \\
\text { untuk cara } \\
\text { melampiaskan } \\
\text { emosi yang } \\
\text { memuaskan bagi } \\
\text { Subjek dengan } \\
\text { membaca doa } \\
\text { ketika takut, } \\
\text { menghindar dan } \\
\text { bermain sendiri, } \\
\text { melakukan tidur } \\
\text { dan mengucapkan } \\
\text { hadist marah } \\
\text { ketika marah }\end{array}$ & $\begin{array}{l}\text { Subjek } \\
\text { melampiaskan } \\
\text { emosi dengan } \\
\text { memarahi teman } \\
\text { yang berperilaku } \\
\text { buruk, bermain } \\
\text { sendiri ketika } \\
\text { ditinggal bermain } \\
\text { teman,menceritakan } \\
\text { perasaan senang, } \\
\text { dan mengucapkan } \\
\text { hadist tidak boleh } \\
\text { marah ketika marah }\end{array}$ & $\begin{array}{l}\text { Subjek } \\
\text { melampiaskan } \\
\text { dengan bersabar, } \\
\text { membaca ayat } \\
\text { kursi ketika takut, } \\
\text { memarahi ketida } \\
\text { merasa dibohongi, } \\
\text { tidur ketika } \\
\text { marah-marah, } \\
\text { menyembunyikan } \\
\text { kemarahan } \\
\text { dibalik guling, } \\
\text { dan mengucapkan } \\
\text { hadist tidak boleh } \\
\text { marah ketika } \\
\text { sedang marah }\end{array}$ \\
\hline $\begin{array}{l}\text { Proses belajar } \\
\text { melalui imitasi }\end{array}$ & $\begin{array}{l}\text { Subjek merespon } \\
\text { pola emosi dari } \\
\text { apa yang dilihat } \\
\text { dilingkungan } \\
\text { sekitar Subjek dan } \\
\text { apa yang telah } \\
\text { diajarkan oleh } \\
\text { orang tua dan } \\
\text { guru Subjek }\end{array}$ & $\begin{array}{l}\text { Subjek merespon } \\
\text { pola emosi dari } \\
\text { rangsangan yang } \\
\text { dilihat dan diterima } \\
\text { orang } \\
\text { dilingkungannya } \\
\text { dalam berperilaku } \\
\text { terhadap keadaan } \\
\text { tertentu }\end{array}$ & $\begin{array}{lr}\text { Subjek } & \text { merespon } \\
\text { pola } & \text { emosi } \\
\text { dengan } & \text { cara } \\
\text { melihat orang } \\
\text { disekelilingnya } \\
\text { dalam bereaksi } \\
\text { seperti direbut, } \\
\text { bermain secara } \\
\text { berlebihan, dan } \\
\text { melihat orang yag } \\
\text { membutuhkan. } \\
\text { Selain itu, Subjek } \\
\text { juga melalui } \\
\text { proses belajar } \\
\text { emosi dari sebuah } \\
\text { media aplikasi } \\
\text { WA, televise dan } \\
\text { metode cerita }\end{array}$ \\
\hline Proses belajar & Subjek mengenal & Kondisi lingkungan & Kondisi \\
\hline
\end{tabular}




\begin{tabular}{llll}
\hline melalui & berbagai macam Subjek merangsang lingkungan \\
pengkondisian & emosi marah, untuk menstimulasi & Subjek \\
& sedih, takut, dan emosi baik emosi & mengajarkan \\
& khawatir dalan positif maupun untuk & memunculkan \\
& kondisi tertentu. emosi negatif & macam-macam \\
& Selain itu juga, & respon emosi \\
& Subjek juga & yang secara cepat \\
belajar melalui & \\
pengkondisian & \\
& untuk bersabar & \\
& dalam & \\
& mengendalikan & \\
emosi & & \\
\hline
\end{tabular}

Adanya gambaran kematangan emosi yang bervariasi tentunya tidak terlepas dari faktor-faktor yang memengaruhi terbentuknya kematangan emosi pada anak prasekolah $^{[2]}$. Faktor-faktor tersebut yaitu pola asuh orang tua, temperamen, jenis kelamin, usia perkembangan kematangan emosi yang sejalan dengan bertambahnya usia, perubahan jasmani, dan interaksi dengan teman sebaya menurut Astuti (2006; dalam Dewi, 2015).

Faktor pertama yakni pola asuh. Pola asuh yang diterapkan dalam lingkungan keluarga subjek I adalah dengan mengenalkan macam-macam emosi melalui aktivitas sehari-hari, seperti menerapkan kedisiplinan, menanamkan kepedulian, ringan tangan pada orang yang membutuhkan, dan mengontrol emosi negatif dengan cara sabar dalam hal apapun. Sedangkan pola asuh subjek II lebih melalui pendekatan antara anak dengan orang tua walapun kedua orang tua bekerja. Ibunya mengajarkan untuk selalu terbuka, menceritakan apa yang terjadi, dan memberikan waktu tersendiri untuk anaknya bercerita. Ia juga memberikan perilaku emosi positif, salah satunya memeluk dan mencium. Tak hanya itu, ibu dari subjek II mengajarkan untuk tidak meluapkan emosi dengan cara fisik atau kekerasan. Pada subjek III, pola asuh yang diterapkan hampir sama dengan subjek II, yakni mencoba untuk melakukan pendekatan dengan saling terbuka menceritakan apa yang terjadi, mengungkapkan emosi yang sedang dialami, dan mengajarkan cara mengendalikan emosi dengan cara-cara islami, seperti beristighfar, membaca ayat kursi, mengucapkan rasa syukur, mengajarkan rasa kepedulian,. Ketiga subjek memiliki kedekatan yang baik dengan ibu daripada ayahnya. Hal ini sesuai dengan yang dikemukakan oleh Papilia, pada anak prasekolah, terlihat adanya hubungan antara keamanan keterikatan (attachment) dengan ibu dan pemahaman tentang emosi negatif orang lain ${ }^{[12]}$. Penelitian Fellasari dan Lestari (2016) mengatakan bahwa pola asuh orang tua memengaruhi kematangan emosi seseorang, baik pola asuh authoritative, authoritarian dan permissive ${ }^{[3]}$.

Kedua, faktor temperamen. Tingkat emosi atau temperamen cenderung konsisten dan berkesinambungan serta dapat berkembang seiring munculnya emosi dan kemampuan dalam mengolahnya ${ }^{[12]}$. Temperamen subjek I adalah anak yang mudah diatur, menerima hal baru, beradaptasi dengan lingkungan, menerima makanan dan orang baru, dan selalu tenang dalam menghadapi sesuatu. Subjek II 
adalah anak berpendirian kuat, memiliki keinginan belajar akan hal baru, mudah diatur, memiliki kebiasaan yang teratur, kreatif, dan mudah beradaptasi. Berbeda dengan subjek I dan II, subjek III cenderung sulit beradaptasi, mudah dipengaruhi oleh orang lain sehingga timbul perasaan marah dan kesal, takut dengan orang baru, cenderung berhati-hati, dan perhatiannya sulit dialihkan. Dengan karakteristik yang berbeda, maka ketiga subjek memiliki cara masing-masing dalam merespon emosi yang dihadapi.

Selanjutnya adalah faktor jenis kelamin. Subjek terdiri dari 2 laki-laki dan satu perempuan. Perbedaan jenis kelamin dapat memengaruhi karakteristik emosi anak. Kematangan emosi pada wanita lebih rendah dibandingkan laki-laki ${ }^{[25]}$. Dari segi faktor usia, ketiga subjek memiliki usia yang relatif sama yaitu rata-rata usia 6 tahun. Selain itu, ketiga subjek memiliki perubahan fisik yang sesuai dengan standar tingkat usia jika ditinjau dari faktor perubahan fisik. Penerimaan kondisi tubuh dapat memengaruhi kondisi emosi pada anak. Kemudian, faktor interaksi teman sebaya, di mana ketiga subjek mampu membangun hubungan interaksi dengan teman baik di rumah maupun sekolah dengan baik. Saat berinteraksi dengan teman sebaya, tak jarang timbul konflik emosi sehingga dapat menambah pemahaman tentang emosi anak untuk guru siswa tersebut. Hal ini sejalan dengan pendapat Nurmalitasari bahwa perkembangan emosi juga berpengaruh terhadap perkembangan sosial anak. Interaksi sosial membutuhkan kemampuan khusus yang diikuti oleh kondisi emosi anak, seperti motivasi, empati dan menyelesaikan konflik $^{[10]}$ (Ulfa \& Syafrizaldi, 2017).

Selanjutnya, faktor kematangan kognitif (mental). Subjek I memiliki daya pemikiran, banyak gagasan, dan kemampuan dalam mengatasi masalah yang dihadapi. Sedangkan subjek II memiliki kemampuan untuk mengategorisasi, bereksplorasi, aktif, dan inisiatif untuk melakukan hal baru dan memiliki kemampuan untuk memecahkan masalah yang dihadapi. Subjek III memiliki rasa tanggung jawab, aktif, bereksplorasi, dan mengategorisasi. Faktor selanjutnya adalah proses belajar mencoba-coba. Subjek I melampiaskan emosi positif maupun negatif dengan cara yang pernah diajarkan sebelumnya. Ketika subjek I merasa diganggu oleh temannya, ia mencoba untuk menghindar dan tidak membalas. Menurut dirinya, apabila dibalas maka akan terjadi prkelahian sehingga ia lebih memilih untuk bermain sendiri. Selain itu, ketika subjek I ingin marah atau merasa takut, ia menenangkan diri dengan membaca doa seperti yang diajarkan dan diingatkan oleh orang tua subjek. Berbeda dengan subjek I, subjek II lebih berani mengungkapkan emosinya secara verbal. Ketika dia melihat temannya berperilaku buruk terhadap dirinya, ia langsung memberi peringatan. Selain itu, subjek II selalu menceritakan apa yang terjadi pada dirinya, baik emosi positif maupun negatif kepada ibunya. Hal itu dilakukan karena orang tua subjek selalu menanyakan kabar si anak, memberikan waktu luang, dan berusaha untuk saling terbuka. Ketika subjek II sedang ingin marah, sama dengan subjek I dan III, ketika diingatkan oleh guru di sekolah mereka akan mengucapkan hadis "Laa taghdhab walakal jannah". Pada subjek III, cara melampiaskan emosinya adalah dengan menghiraukan dan tidak membalas perbuatan buruk orang lain. Hal tersebut dilakukan karena ibu subjek selalu mengingatkan untuk bersabar, menenangkan untuk tidak perlu membalas, dan membaca ayat kursi seperti yang diajarkan oleh ibunya ketika merasa takut dan gelisah. 
Kemudian, faktor proses belajar melalui imitasi. Subjek I mengenal emosi marah, sedih, dan perasaan sensitif ketika menerima stimulus dari ayahnya saat keinginannya tidak terpenuhi, temannya tidak mengizinkannya untuk bermain bersama, dan ibunya sengaja mengabaikannya karena marah. Subjek II mengenal emosi marah, sedih dan rasa iba ketika melihat temannya diganggu oleh yang lain, saat dirinya tidak diajak bermain sehingga membuatnya sedih, dan ketika melihat pengemia seusianya di pinggir jalan. Sedangkan subjek III akan marah dan menangis ketika kakaknya memukul dan berbuat curang kepadanya. Ia juga merasa iba ketika melihat pengemis di jalan sehingga tergerak hatinya untuk memberi. Selain itu, subjek III belajar mengenal emosi melalui media seperti yang diajarkan oleh ibunya. Ketiga subjek menirukan hadis tidak boleh marah seperti yang diajarkan guru di sekolah.

Terakhir, faktor proses belajar melalui pengondisian. Pada proses belajar, ketiga subjek sama-sama mendapatkan pengalaman untuk mengenal dan memahami emosi dari lingkungan sekolah, keluarga, dan tempat umum. Orang tua dan guru ikut serta dalam memberikan rangsangan untuk menstimulasi emosi pada ketiga subjek, baik emosi positif maupun emosi negatif.

\section{SIMPULAN DAN IMPLIKASI}

Berdasarkan hasil penelitian, dapat disimpulkan bahwa kematangan emosi pada siswa TK B yang memiliki kematangan kognitif tinggi menunjukkan gambaran yang bervariasi, ada yang sama dan ada pula yang berbeda. Ketiga subjek dapat memunculkan masing-masing aspek dalam kematangan emosi. Dalam mencapai kematangan emosi, terdapat faktor-faktor yang memengaruhi, baik faktor internal maupun eksternal yang meliputi pola asuh orang tua, temperamen, jenis kelamin, usia perkembangan, perubahan jasmani, dan interaksi dengan teman sebaya. Selain itu, terdapat faktor lain yang turut memengaruhi, yaitu kematangan kognitif (mental), proses belajar, dan pengalaman belajar. Faktor yang memengaruhi respon emosi pada anak meliputi proses belajar mencoba-coba, proses belajar secara imitasi, dan proses belajar secara pengondisian. Penelitian ini juga memiliki kelemahan, yakni tidak dapat mengungkap gambaran pada jenis kelamin, faktor usia perkembangan dan perubahan fisik, sebab usia dan gambaran fisik anak relatif sama. Implikasi untuk penelitian ini adalah diharapkan guru dan orang tua mengembangkan kematangan emosi dengan mempertimbangkan karakteristik anak, di antaranya yaitu kognitif anak.

\section{REFERENSI}

Davidoff, L. L. (1991). Psikologi Suatu Pengantar . Jakarta : Erlangga.

Dewi, YK.(2016). Hubungan Antara Kematangan Emosi Anak Usia Dini Dan Metode Bcct (Beyond Center And Circles Time) Ditinjau Dari Pemahaman Orang Tua Dan Guru Di Paud Pelangi Dan Mega Buana .. [Online] Tersedia: [Diakses: 20 September 2017]

Fellasari, F., \& Yuliana, I. L. ( 2016). Hubungan Antara Pola Asuh Orangtua Dengan Kematangan Emosi Remaja . Jurnal Psikologi , 84-90.

Hamiyah, N., \& Mohammad, J. ( 2015). Pengantar Manajemen Pendidikan Di Sekolah. Jakarta : Prestasi Pustakaraya. 
Howse, R. B., Susan, D. C., Arthur D. Anastopoulos, D. A., Susan, P. K., \& Terri, L. S. (2003). Regulatory Contributors to Children's Kindergarten Achievement . Early Education and Development, 101-119.

Hurlock, E. B. (1980). Suatu Pendekatan Sepanjang Rentang Kehidupan Edisi Kelima . Jakarta: Erlangga.

Izzaty, R. E. (n.d.). Prediktor Permasalahan Perilaku Anak Usia Taman Kanak-Kanak. Thesis, tidak diterbitkan. Yogyakarta : Program Pasca Sarjana Universitas Gadjah Mada.

Mariyati, L. I., \& Ghozali, R. A. (2016). Tepatkah Nijmeegse Schoolbekwaamheids Test (Nst) Untuk Mengukur Kesiapan Sekolah Siswa Sekolah Dasar Awal Pada Konteks Indonesia? (Analisis Empirik Berdasar Teori Tes Klasik) [Online]. Tersedia : http://ejournal.umm.ac.id/index/php/jipt/article/viewFile/3520/4056 [Diakses 27 Februari 2019].

Moleong, L. J. (2007). Metodologi Penelitian Kualitatif . Bandung: Pt Remaja Rosdakarya.

Nurmalitasari, F. (2015). Perkembangan Sosial Emosi Pada Anak Usia Prasekolah. Buletin Psikologi . [Online]. Tersedia :

https://journal.ugm.ac.id/buletinpsikologi/article/view/10567 [Diakses 20 Januari 2019].

Papalia, Diane, E., Sally, W. O., \& Ruth, D. F. (2009). Human Development Perkembangan Manusia Edisi 10. Jakarta : Salemba Humanika.

Papalia, Diane, E., Sally, W. O., \& Ruth, D. F. (2010). Human Development Psikologi Perkembangan Edisi Kesembilan. Jakarta : Kencana.

Patmonodewo, S. (2003). Pendidikan Anak Prasekolah. Jakarta : Pt Rineka Cipta.

Santrock, J. W. (2002). Life-Span Development Perkembangan Masa Hidup Jilid I. Jakarta : Erlangga.

Santrock, J. W. (2007). Perkembangan Anak Edisi Kesebelas Jilid II. Jakarta: Erlangga.

Santrock, J. W. (2012). Life-span Development Perkembangan Masa Hidup edisi ketigabelas jilid 1 alih bahasa Benedistine Wisdyasinata. jakarta : erlangga .

Sharma, D., \& Sushma, S. (2018). Relationship between motivation and academic achievement . International Journal of Advances in Scientific Research , 01-05.

Somantri, S. ( 2006). Psikologi Anak Luar Biasa . Bandung: PT Refika Aditama.

Stan, M. M. (2013). Socio-emotional predictors of school success at the beginning of school years . procedia- Social and Behavioral Sciences , 806-810.

Sudjana, N. ( 2005). Penilaian Hasil Proses Belajar Mengajar. Bandung : Remaja Rosdakarya.

Sugiyono. (2015). Metode Penelitian Kuantitatif Kualitatif Dan R\&D. Bandung: Alfabeta.

Sugiyono. (2016). Metode Penelitian Manajemen. Bandung: Alfabeta.

Sulistyaningsih, W. (2005). Kesiapan Bersekolah Ditinjau Dari Jenis Pendidikan Prasekolah Anak Dan Tingkat Pendidikan Orang Tua. Jurnal Psikologiani [Online]. Tersedia : http://www.scribd.com/doc/137541957/Psikologia-Vol-1-No-1-Juni-2005 [Diakses 28 Februari 2019]

Susanto, A. (2011). Perkembangan Anak Usia Dini, Pengantar Dalam Berbagai Aspeknya. Jakarta : Kencana Prenada Media Group

Ulfa, S. A., \& Syafrizaldi, S. (2017). Perbedaan Kematangan Emosi Ditinjau Dari Jenis Kelamin Pada Remaja Di Smas Sinar Husni Medan. Jurnal Diversita , 59-65. 